\title{
MENENGOK KESEDERHANAAN PENGELOLAAN PERPUSTAKAAN MADRASAH ALIYAH NEGERI MALAKAJI KABUPATEN GOWA
}

\author{
Sitti Arafah \\ Balai Penelitian dan Pengembangan Agama Makassar, \\ Sulawesi Selatan, Indonesia \\ sittiarafah0702@gmail.com
}

\begin{abstract}
This research is aimed to describe the related library management MAN 1 Malakaji based on National Standar Library (SNP). The research is qualitative by using data collection methode through observation, interview and document. The result showed that the library in MAN 1 Malakaji is still managed simply. Facalities and infrastructure, collections, librariries and library services, as indicator in the management of libraries in MAN 1 Malakaji can not be fulfilled maximally. But on the other hand stakeholder, role in managing and developing librarian at MAN 1 Malakaji have big share either government, school and society.
\end{abstract}

Keyword: Management, Library, MAN 1

\begin{abstract}
Abstrak
Penelitian ini bertujuan untuk mendeskripsikan terkait pengelolaaan perpustakaan pada Madrasah Aliyah Negeri 1 Malakaji, berdasarkan (Standar Nasional Perpustakaan). Penelitian ini adalah kualitatif dengan metode pengumpulan data melalui observasi, wawancara dan dokumen. Hasil
\end{abstract}


penelitian menunjukkan bahwa perpustakaan MAN Malakaji masih dikelola secara sederhana. Sarana dan prasarana perpustakaan, koleksi perpustakaan, tenaga perpustakaan dan layanan perpustakaan sebagai indikator dalam pengelolaan perpustakaan pada MAN 1 Malakaji belum dapat terpenuhi secara maksimal. Namun disisi lain peran stakeholder dalam pengelolaan dan pengembangan perpustakaan di MAN 1 Malakaji memiliki andil yang besar baik pemerintah, sekolah dan masyarakat.

Kata Kunci: Pengelolaan, Perpustakaan, MAN 1

\section{A. Pendahuluan}

Dampak transparansi perkembangan ilmu pengetahuan dan teknologi, mengakibatkan terjadinya ledakan informasi yang begitu cepat dan pesat. Sebagai konsekuensi logis mempengaruhi pada semua lapisan kehidupan termasuk kehidupan organisasi. Perpustakaan sebagai suatu organisasi dan pusat informasi tidak dapat terhindar dari dampak perkembangan teknologi informasi yang telah mengubah wahana penyampaian informasi kepada pengguna. Namun untuk perpustakaan sekolah/madrasah yang termasuk salah satu jenis perpustakaan di Indonesia, jangankan pelayanan yang berbasisi teknologi informasi, masih banyak diantara sekolah/madrasah yang belum memiliki perpustakaan ${ }^{1}$

United Nations Development Programme (UNDP), misalnya, menyebutkan dalam hal minat baca, Indonesia menempati peringkat 96, sejajar dengan Bahrain, Malta, dan Suriname. Bahkan untuk kawasan Asia Tenggara, hanya ada dua negara di bawah peringkat Indonesia, yakni Kamboja dan Laos. Data ini diperkuat oleh survei yang dikeluarkan oleh UNESCO yang menunjukkan bahwa minat baca masyarakat Indonesia paling rendah di ASEAN adalah Indonesia. Rendahnya minat baca ini dibuktikan dengan indeks membaca masyarakat Indonesia yang baru sekitar 0,001,

${ }^{1}$ Irawaty Kahar, "Pola Strategi Sinergis Pengembangan Perpustakaan Sekolah,” Jurnal Tabularasa PPS UNIMED Vol. 6, No. 2 Desember (2009): 126. 
artinya dari 1000 penduduk, hanya ada satu orang yang masih memiliki minat baca tinggi (1:1000). Angka ini masih sangat jauh dibandingkan dengan angka minat baca di Singapura yang memiliki indeks membaca sampai $0,45 .^{2}$

Dalam Undang-Undang Nomor 43 Tahun 2007 tentang Perpustakaan menyebutkan bahwa pemerintah berkewajiban menggalakkan promosi gemar membaca dan memanfaatkan perpustakaan. Perpustakaan sekolah/madrasah merupakan sarana efektif dalam meningkatkan minat baca peserta didik karena mampu menumbuhkan kebiasaan membaca secara disiplin lewat jalur pendidikan formal. Oleh sebab itu peran guru di sekolahsekolah sangat mempengaruhi kecenderungan membaca anak. Para guru paling tidak harus mempunyai pengetahuan dasar tentang teknik dan strategi untuk menumbuhkan dan meningkatkan minat baca anak didik mereka. Misalnya membekali setiap murid dengan kartu yang mencatat jumlah buku yang dibaca (selain buku pelajaran) selama satu atau dua minggu yang kemudian mewajibkan si anak untuk menceritakan kembali hasil bacaannya tersebut di depan kelas. Bisa juga dengan membentuk klub-klub pecinta buku, majalah dinding, dan kegiatan-kegiatan ekstra kurikuler lainnya di sekolah yang ada hubungannya dengan pembinaan minat baca. ${ }^{3}$

Di tingkat sekolah/madrasah, perpustakaan sudah selayaknya mendapatkan porsi dan posisi yang strategis guna ikut merealisasikan tujuan pendidikan. Semua pihak, khususnya kepala sekolah harus memberi perhatian lebih akan eksistensi perpustakaan di sekolah, dan tidak lagi dianggap sebagai tempat menyimpan buku bekas, barang-barang tidak terpakai, bahkan tempat bermain saat tidak ada kegiatan belajar mengajar. Perpustakaan sekolah/ madrasah sebagai salah satu jenis perpustakaan yang berkaitan erat

\footnotetext{
${ }^{2}$ Abu Muslim, “Membaca Eksistensi 'Pusat Literasi’Dari Pelosok Negeri: Ironi Pengelolaan Perpustakaan Madrasah Aliyah Konawe Selatan," Penamas Vol. 28, No. 1, April-Juni, no. 1 (2015): 26.

3 Agus Saputera, "Mengembalikan Peran Perpustakaan Sekolah/ Madrasah," March 3, 2010, https://riau2.kemenag.go.id/artikel/10050/ mengembalikan-peran-perpustakaan-sekolah-madrasah.
} 
dengan kegiatan pendidikan formal di sekolah mempunyai peran yang sangat efektif dan strategis untuk meningkatkan minat baca siswa. Perpustakaan sekolah dewasa ini tidak saja merupakan unit kerja yang menyediakan bacaan guna menambah pengetahuan dan wawasan bagi murid, tetapi juga merupakan bagian yang integral dari kegiatan pembelajaran. Artinya, penyelenggaraan perpustakaan sekolah harus sejalan dengan visi dan misi sekolah dengan mengadakan bahan bacaan bermutu yang sesuai kurikulum, menyelenggarakan kegiatan yang berkaitan dengan bidang studi, dan kegiatan penunjang lain. ${ }^{4}$

Untuk menjadikan perpustakaan sebagai sumber informasi dan sumber belajar maka perlu mendapatkan perhatian yang lebih utama pada aspek pengelolaanya. Ada beberapa hal yang perlu dipersiapkan antara lain sarana dan prasarana, sumber daya manusia, jumlah koleksi. Secara umum di dalam perpustakaan merupakan tempat untuk melakukan kegiatan penghimpunan, pengelolaan dan pelayanan segala macam informasi baik yang tercetak maupun yang terekam dalam berbagai media antara lain: majalah, buku, surat kabar, film, recorder, komputer dan lainnya. ${ }^{5}$

Kabupaten Gowa Sulawesi Selatan sebagai salah satu daerah yang melakukan kebijakan pendidikan gratis bagi jenjang SD/MI hingga SMA/MA. Dengan adanya program pendidikan gratis di Gowa, maka indikator keberhasilannya bisa dilihat dari animo masyarakat yang menyekolahkan anaknya mulai dari tingkat dasar hingga menengah, sehingga pengelola satuan pendidikan tertentu kelihatam kesulitan menampung calon peserta didik yang membludak. Permasalahan yang muncul kemudian adalah apakah sekolah atau madrasah semuanya memiliki perpustakaan sebagai sumber informasi bagi peserta didik.

${ }^{4}$ Abu Muslim, "Pengelolaan Perpustakaan Madrasah Aliyah Di KTI," in Desain Operasional Penelitian Balai Penelitian Dan Pengembangan Agama Makassar, 2014, 2.

5 Pawit M. Yusuf and Yaya Suhendar, Pedoman Penyelenggaraan Perpustakaan Sekolah (Jakarta: Prenada Media Group, 2007), 1. 
Penelitian ini akan mencoba melihat tentang pengelolaan perpustakaan Madrasah Aliyah, secara khusus pada Madrasah Aliyah Negeri, apakah pengelolaannya telah sesuai dengan Standar Nasional Perpustakaan (SNP) yang berfungsi dalam memberikan pelayanan pendidikan melalui perpustakaan.

\section{Rumusan Masalah}

Berdasarkan latar belakang tersebut, maka permasalahan pokok dalam penelitian ini adalah bagaimana penyelenggaraan perpustakaan di MAN Malakaji Kabupaten Gowa? Selanjutnya dirumuskan beberapa sub masalah yakni:

a. Bagaimana pengelolaan Perpustakaan MAN Malakaji Kab. Gowa?

b. Bagaimana peran stakeholder dalam penyelenggaraan perpustakaan MAN Malakaji Kab. Gowa?

\section{Tujuan dan Kegunaan Penelitian}

Tujuan penelitian ini adalah untuk memperoleh jawaban yang akurat terhadap pertanyaan-pertanyaan tersebut yang diangkat sebagai masalah penelitian, yaitu:

a. Mendeskripsikan tata kelola penyelenggaraan perpustakaan MAN Malakaji.

b. Mendapatkan informasi terkait faktor pendukung dan penghambat penyelenggaraan perpustakaan madrasah di Kabupaten Gowa.

c. Untuk mengetahui peran stakeholder terhadap pengelolaan perpustakan MAN Malakaji Gowa.

Hasil penelitian ini diharapkan menjadi acuan dan pertimbangan bagi pemerintah, dalam hal ini kementerian agama dan segenap jajarannya serta pemerintah daerah setempat dalam meningkatkan pengelolaan dan fungsi perpustakaan madrasah dalam rangka meningkatkan kualitas pendidikan agama di berbagai tingkatan satuan pendidikan agama dan keagamaan. Selain itu 
diharapkan pula berguna bagi para pengelola perpustakaan untuk meningkatkan sistem pengelolaannya.

\section{Tinjauan Pustaka}

Perpustakaan adalah suatu tempat yang di dalamnya terdapat kegiatan penghimpunan, pengelolaan dan penyebarluasan (pelayanan) segala macam informasi, baik yang tercetak maupun yang terekam dalam bentuk media, seperti buku, majalah kaset, film, video komputer dan lain-lain. ${ }^{6}$

Dalam Undang-Undang Nomor 43 Tahun 2007, perpustakaan adalah institusi pengelola koleksi karya tulis, karya cetak, dan/atau karya rekam secara profesional dengan sistem yang baku guna memenuhi kebutuhan pendidikan, penelitian, pelestarian, informasi, dan rekreasi para pemustaka. ${ }^{7}$ Pada pasal 11 bab III dijelaskan juga mengenai standar nasional perpustakaan yang digunakan sebagai acuan penyelenggaraan, pengelolaan, dan pengembangan perpustakaan yang terdiri atas:
a. Standar koleksi perpustakaan
b. Standar sarana dan prasarana
c. Standar pelayanan perpustakaan
d. Standar tenaga perpustakaan
e. Standar penyelenggaraan
f. Standar pengelolaan. ${ }^{8}$

Perpustakaan Madrasah Aliyah yang merupakan perpustakaan yang berada pada satuan pendidikan formal di lingkungan pendidikan menengah merupakan bagian integral dari kegiatan sekolah yang bersangkutan, dan merupakan pusat sumber belajar untuk mendukung tercapainya tujuan pendidikan sekolah yang bersangkutan. Perpustakaan sekolah menengah atas/madrasah

${ }^{6}$ Muh Subair, "Standarisasi Pengelolaan Perpustakaan MA Di Kabupaten Gorontalo," Jurnal Pusaka Vol. 2 No. 1 Mei (2014): 2.

7 Indonesia, Undang-Undang Republik Indonesia nomor 43 tahun 2007 Tentang Perpustakaan (Perpustakaan Nasional, 2007), 2.

${ }^{8}$ Indonesia, 8. 
secara rinci dan jelas selanjutnya dimuat dalam buku panduan Standar Nasional Perpustakaan Sekolah dan perguruan tinggi. ${ }^{9}$

Secara rinci, Perpustakaan Nasional RI mengeluarkan semacam pedoman standarisasi pengelolaan perpustakaan perguruan tinggi dan sekolah yang dijadikan sebagai konsensus bersama dalam penyelenggaraan perpustakaan. Berikut secara khusus disajikan standar nasional perpustakaan sekolah menengah atas/madrasah aliyah yang meliputi standar koleksi, sarana prasarana, layanan, tenaga, penyelenggaraan, pengelolaan, pengorganisasian bahan perpustakaan, anggaran, perawatan, kerjasama dan integrasi dengan kurikulum. Standar ini berlaku pada perpustakaan sekolah menengah atas/madrasah aliyah baik negeri maupun swasta. Secara normatif, SNP madrasah aliyah ini mengacu pada Permendiknas No.24 Tahun 2007 Tentang Standar Sarana dan Prasarana Untuk Sekolah Dasar/Madrasah Ibtidaiyah (SD/MI), Sekolah Menengah Pertama/Madrasah Tsanawiyah (SMP/MTs), dan Sekolah Menengah Atas/Madrasah Aliyah(SMA/ MA). ${ }^{10}$

Rahayuningsih dalam bukunya yang berjudul Pengelolaan Perpustakaan menyebutkan bahwa sangatlah penting untuk mengembangkan perpustakaan modern yang efektif dan efesien. Secara garis besar, cakupan yang terkandung dalam buku ini adalah:

a. Pengantar umum perpustakaan yang mencakup tujuan didirikannya perpustakaan, berbagai jenis perpustakaan dan fungsinya, perencanaan gedung perpustakaan, komputerisasi perpustakaan, dan kegiatan pokok perpustakaan.

${ }_{9}$ R. I. Perpustakaan Nasional, Standar Nasional Perpustakaan (SNP) Bidang Perpustakaan Sekolah Dan Perpustakaan Perguruan Tinggi (Jakarata: Perpusatakaan Nasional RI, 2011).

${ }^{10}$ Perpustakaan Nasional RI, Daftar Tajuk Subjek Perpustakaan Nasional (Jakarta: Perpustakaan Nasional RI, 2010). 
b. Pengembangan koleksi yang memuat tentang pemilihan, pemesanan, pembelian dan inventarisasi bahan pustaka, baik buku maupun terbitan berkala.

c. Pengolahan koleksi: penentuan subjek, klasifikasi penentuan tajuk, entri data, dan pemberian kelengkapan koleksi agar dapat dilayankan kepada pemustaka.

d. Layanan pengguna: jenis layanan, system layanan, layanan sirkulasi, layanan refrensi, layanan terbitan berkala, layanan pendidikan pengguna.

e. Pemeliharaan koleksi: sumber penyebab kerusakan koleksi, akibat yang ditimbulkan cara mengatasi kerusakan dan kegiatan pemeliharaan koleksi. ${ }^{11}$

\section{Metode Penelitian}

Penelitian ini merupakan penelitian deskriptif kualitatif yang bertujuan untuk mendapatkan gambaran mengenai pengelolaan perpustakaan Madrasah Aliyah Negeri Malakaji Kabupaten Gowa sebagai sasaran penelitian. Pendekatan yang lazim digunakan dalam pengumpulan data adalah wawancara melalui dua pola yakni terstruktur dan bebas (mendalam), observasi yakni melakukan pengamatan langsung pada lokasi perpustakaan untuk melihat sejauh mana pengelolaan yang dilakukan di perpustakaan dan dokumentasi dimaksudkan untuk melihat dokumen dalam pengelolaan perpustakaan seperti pencatatan pelayanan, pencatatan koleksi. ${ }^{12}$

Analisis adalah sistem yang diterapkan dengan menggunakan teori yang obyektif. Sedangkan analisis yang dilakukan melakukan reduksi data dan display data untuk memperoleh analisis deskriptif terkait pengelolaan perpustakaan MAN 1 Malakaji Kabupaten Gowa. 2007), ix.

${ }^{11}$ F. Rahayuningsih, Pengelolaan Perpustakaan (Jogjakarta: Graha Ilmu,

12 John Cresswell, Research Design, Qualitative and Quantitative Approaches (California: Thousand Oaks, 1994), 36. 


\section{B. Pembahasan}

\section{Profil Madrasah Aliyah Negeri Malakaji Kab. Gowa}

Madrasah Aliyah Negeri (MAN) 1 Malakaji adalah salah satu Madrasah Aliyah di Kabupaten Gowa berstatus negeri dengan akreditasi A, beralamat di Jalan Masjid Raya No. 1 Malakaji, berdiri pada tahun 1997. MAN Malakaji dilengkapi dengan sarana dan prasarana antara lain: 13 ruang belajar, 1 ruang kantor, 1 ruang perpustakaan, dengan kondisi bangunan permanen dan saat ini telah dilakukan penambahan ruang belajar, dan untuk pembiayaan operasional madrasah melalui dana BOS kementerian agama pusat dan pendidikan gratis pemerintah Kabupaten Gowa.

\section{Pengelolaan Perpustakaan Madrasah Aliyah Negeri Malakaji}

a. Sarana dan Prasarana Perpustakaan MAN Malakaji

MAN Malakaji sebagai Madrasah yang berstatus negeri dengan akreditasi A dalam pengelolaan perpustakaannya terkait sarana dan prasarana telah memiliki perpustakaan gedung tersendiri yang letaknya berada di tengah-tengah kompleks madrasah dan dapat dijangkau dengan mudah oleh pemustaka. Perpustakaan MAN Malakaji dengan luas area $7 \times 9 \mathrm{~m}^{2}$, area koleksi $4 \times 5 \mathrm{~m}$, area staf/pengelola $3 \times 4 \mathrm{~m}$, area baca seluas $4 \times 7 \mathrm{~m}$, tidak terdapat area multi media, kondisi pengaturan area tertata dengan rapi.

Di samping itu pada ruang perpustakaan terdapat sarana dan prasarana antara lain: 4 buah rak buku, 4 buah meja baca dengan ukuran panjang, 26 buah kursi baca, 3 buah meja kerja, 3 buah kursi kerja, serta 2 buah meja sirkulasi, 1 buah rak referensi, disimpan di ruang kepala sekolah dengan alasan pengamanan koleksi, karena banyaknya buku referensi yang dipinjam baik oleh guru maupun siswa tidak dikembalikan. Selanjutnya terdapat 1 buah komputer, yang berada di ruang kepala perpustakaan yang hanya digunakan oleh pengelola perpustakaan untuk mengakses informasi, selanjutnya terdapat 1 buah tempat sampah dan 1 buah 
jam dinding, dan tidak terdapat alat audio visual baik TV maupun DVC/VCD. ${ }^{13}$

\section{b. Koleksi Perpustakaan MAN Malakaji}

Koleksi perpustakaan adalah semua pustaka yang dikumpulkan, diolah dan disimpan untuk disebarluaskan kepada masyarakat guna memenuhi kebutuhan informasi mereka. Koleksi perpustakaan merupakan unsur utama dalam penyelanggaraan layanan pepustakaan untuk menunjang pelaksanaan pendidikan.

Agar koleksi perpustakaan mudah ditemukan dan digunakan oleh pemustaka, dilakukan kegiatan pengolahan bahan pustaka di perpustakaan dalam bentuk penginventarisasian, pemberian tanda, pengklasifikasian, pengkatalogisasian, dan penyusunan koleksi di rak buku sesuai dengan klasifikasinya. ${ }^{14}$

Koleksi-koleksi yang terdapat pada perpustakaan MAN Malakaji terdiri dari koleksi umum yakni buku-buku pegangan pada setiap mata pembelajaran umum, disamping terdapat pula koleksi agama, yakni buku paket pelajaran PAI walaupun tidak semua mata pelajaran memiliki buku paket. Koleksi buku paket yang ada di perpustakaan adalah buku paket dengan materi kurikulum berbasis kompetensi tahun 2004 dan KTSP tahun 2009 yang merupakan bantuan dari pendidikan gratis, sehingga hanya menjadi bahan bacaan pembanding bagi para siswa.

Jumlah koleksi yang terdapat pada perpustakaan sebanyak 7329 eksemplar yang sebagian kondisi bukunya rusak dan sobek sehingga tidak lagi dipergunakan oleh pemustaka. Sedangkan buku-buku yang ada sekarang hanya buku penunjang atau buku paket kurikulum untuk setiap mata pelajaran terbitan tahun 20082009 yang diterima oleh pihak sekolah dari pendidikan gratis pada tahun 2010 dan 2011, buku penunjang kurikulum sebanyak 1478 eksemplar. Untuk referensi sebanyak 250 eksemplar dan terbitan

${ }^{13}$ Masdiana, March 2, 2014.

${ }^{14}$ Ibrahim Bafadal, Pengelolaan Perpustakaan Sekolah (Jakarta: Bumi Aksara, 1996), 86. 
berkala 1 yang berasal dari Jakarta. Adapun jenis-jenis referensi antara lain:

1) Ensklopedia Dunia Islam 10 eksemplar

2) Tafsir al-Qur'an KH. Daud Ismail 10 eksemplar

3) Terjemahan al-Qur'an secara lafdziah 10 eksemplar

4) Mashail Fiqhiyah al-Haditsan 20 eksemplar

5) Perbandingan Mazhab 26 eksemplar

6) Intelektualisme Pesantren 6 eksemplar

7) Dinamika Lintas Perjuangan Pemuda Papua 6 eksemplar

8) Pendidikan Agama untuk Membangun Etika 6 eksemplar

9) dan lainya masing-masing 1 eksemplar

Koleksi-koleksi bahan pustaka yang terdapat pada perpustakaan telah dikelompokkan/diklasifikasikan berdasarkan judul dan jenisnya. Koleksi tersebut telah diberi label pada punggung buku, dan telah diklasifikan berdasarkan jenisnya. Dan sebagian koleksi dirawat dengan melakukan pencahayaan dan memisahkan antara koleksi-koleksi yang telah usang dan tidak terpakai lagi disimpan pada lemari atau kardus.

c. Tenaga Perpustakaan MAN Malakaji

Untuk menjadi seorang pustakawan tidaklah mudah, ia harus memiliki kompetensi tertentu. Kompetensi adalah suatu pengetahuan, keterampilan, kemampuan atau hal-hal yang berhubungan dengan kinerja yang tinggi dalam pekerjaan. Sumber daya manusia perpustakaan, selama ini yang bertanggung jawab mengelola perpustakaan adalah guru yang disebut guru pustakawan dengan tugas ganda sebagai guru dan sebagai pengelola perpustakaan sekolah/madrasah, dan pada umumnya mereka tidak memiliki dasar pendidikan perpustakaan.

Menurut Anthony, agar pustakawan perpustakaan sekolah itu efektif, harus mempunyai 3 dasar pengetahuan yaitu:

1) Pengetahuan pendidikan 
2) Pengetahuan perpustakaan

3) Pengetahuan teknologi. ${ }^{15}$

Perpustakaan yang baik adalah perpustakaan yang memiliki pengelola yang berfungsi memberikan pelayanan kepada pemustaka. Tenaga perpustakaan yang bertugas sebagai pengelola perpustakaan berjumlah 3 orang, yaitu 1 orang Kepala Perpustakaan yang berstatus PNS dengan kualifikasi pendidikan S1 dan 2 orang lainnya sebagai staf yang berstatus non PNS, berkualifikasi pendidikan S1.

d. Penyelenggaraan dan Pengelolaan Perpustakaan MAN Malakaji

Menilik pada pendirian perpustakaan MAN Malakaji tampaknya belum memiliki Surat Keputusan dan Nomor Pokok Perpustakaan. Di samping itu perpustakaan juga belum memiliki visi dan misi, namun memiliki tujuan yakni meningkatkan pembelajaran dan menjadi sumber belajar bagi siswa. Adapun struktur organisasi perpustakaan MAN Malakaji sebagai berikut:

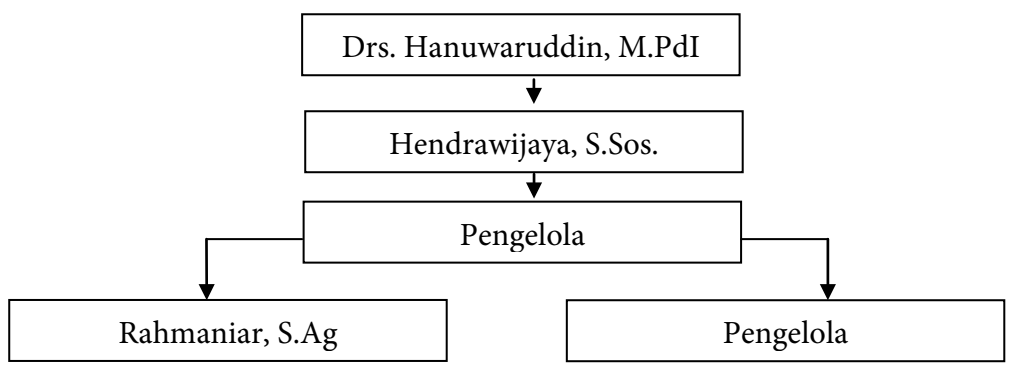

Gambar 1. Struktur Perpustakaan MAN Malakaji

Pelaksanaan program kerja perpustakaan madrasah secara tertulis belum dilakukan, hanya sebatas layanan pada pemustaka (siswa dan guru) namun telah disusun beberapa kegiatan antara lain majalah dinding yang dalam penyusun programnya melibatkan kepala sekolah, guru, pengelola perpustakaan dan siswa. Untuk Sekolah," 129.

15 Kahar, "Pola Strategi Sinergis Pengembangan Perpustakaan 
pengembangan, saat ini tetap melakukan berbagai program antara lain pembangunan gedung perpustakaan baru dimana sumber anggaran berasal dari dana BOS Kementerian Agama, pengadaan buku merupakan bantuan dari pendidikan gratis tahun 2014 berjumlah 20 juta, melalui pendidikan gratis Pemerintah Daerah Kabupaten Gowa. Namun sampai saat ini MAN Malakaji belum menggunakan sistem literasi informasi disebabkan belum adanya sarana dan prasarana yang memadai. ${ }^{16}$

Melihat kondisi perpustakaan MAN Malakaji belum mampu dijadikan sebagai sumber belajar secara utuh, maka dari itu kepala madrasah dalam pengembangan perpustakaan senantiasa melakukan berbagai upaya dan pendekatan kepada pemerintah dalam hal ini kementerian agama dan pemerintah daerah terkait dengan kebutuhan sarana dan prasarana. Di samping itu kepala madrasah senantiasa memberikan solusi yang efektif kepada pengelola perpustakaan dalam meningkatkan mutu pelayanan kepada pemustaka, hal serupa diungkapkan, bahwa:

perpustakaan MANMalakaji untuksaat ini belum dapat dikatakan sebagai sumber belajar, hal ini dikarenakan masih kurangnya sarana dan prasarana yang menunjang hal tersebut. Baik pada koleksi perpustakaan yang dimiliki sekarang ini karena bukubuku yang ada hanya sebatas penunjang saja bagi siswa karena koleksi yang ada merupakan terbitan lama tahun 2008 sementara kurikulum sekolah/madrasah setiap saat berganti, namum koleksi yang ada diperpustakaan tetap digunakan oleh siswa sebagai bahan penunjang belajar. Demikian pula sarana elektronik dinilai belum memadai karena diperpustakaan belum dilengkapi dengan sarana untuk mengakses bahan atau materi pembelajaran sehingga perpustakaan masih perlu pembenahan secara serius jika ingin dijadikan sebagai sumber belajar bagi siswa. ${ }^{17}$

\footnotetext{
${ }^{16}$ Hanuwaruddin, March 3, 2014.

17 Sofyan, March 3, 2014.
} 


\section{e. Layanan Perpustakaan MAN Malakaji}

Layanan merupakan kegiatan atau aktivitas yang sifatnya berujud atau tidak berujud yang dilakukan untuk melayani konsumen dengan memberikan jasa atau barang disertai atau tanpa disertai pemindahan kepemilikan atas suatu benda atau jasa tertentu.

Layanan perpustakaan secara umum dapat dibagi: layanan sirkulasi atau peminjamam koleksi, layanan rujukan, layanan literasi informasi, layanan pendidikan pengguna dan silang layang.

Perpustakaan MAN Malakaji dalam pemberian layanan menggunakan dua sistem layanan yaitu:

1) Layanan terbuka dengan layanan sirkulasi bagi pemustaka dengan beberapa ketentuan yang diberlakukan dalam memberikan layanan kepada pemustaka, yakni seorang pemustaka harus memiliki kartu keaggotaan dan wajib mengikuti peraturan serta prosedur peminjaman yang telah ditentukan oleh pihak pengelola. Untuk waktu pelayanan pemustaka dimulai pada pukul 07.30-14.00 WIB. Adapun layanan yang diberikan kepada pemustaka antara lain:

a) Layanan baca ditempat

Pengelola perpustakaan memberikan pelayanan bagi pemustaka (siswa) pada saat jam pelajaran kosong atau guru yang bersangkutan tidak hadir pada jam pelajaran maka para siswa diwajibkan masuk ke perpustakaan untuk membaca atau menyelesaikan tugas di ruang perpustakaan.

b) Layanan sirkulasi (peminjaman)

Pengelola perpustakaan melayani peminjaman untuk buku bacaan atau penunjang kurikulum kepada pemustaka yang memiliki kartu keanggotaan dengan waktu peminjaman antara 1 sampai 2 hari, dan pemustakan harus mengembalikan sesuai dengan waktu yang ditentukan, mengalami keterlambatan maka 
pengelola melakukan sistem denda sesuai peraturan yakni Rp1000,00/hari, dan jika pemustaka merusak atau menghilangkan buku yang dipinjam maka diwajibkan untuk menggantinya.

2) Sistem layanan tertutup juga diberlakukan pada perpustakaan MAN Malakaji khususnya buku-buku referensi atau rujukan, hal ini dikarenakan banyaknya buku yang dipinjam oleh pemustaka dan tidak lagi dikembalikan. Oleh karena itu, penyimpanan buku referensi atau rujukan serta peminjamanya juga sangat terbatas. Yakni tersimpan di ruang kepala sekolah dan pemustaka terbatas pada guru (pengajar).

\section{Peran stakeholder terhadap pengembangan perpustakaan madrasah}

Undang-Undang Nomor 43 Tahun 2007 tentang Perpustakaan menyebutkan bahwa perpustakaan diselenggarakan berdasarkan asas pembelajaran sepanjang hayat, demokrasi, keadilan, keprofesionalan, keterbukaan, keterukuran, dan kemitraan. Selain itu dalam UU ini mengamanahkan kewajiban kepada pemerintah yang terkait dengan pengelolaan perpustakaan untuk:

a. Menjamin kelangsungan penyelenggaraan dan pengelolaan perpustakaan sebagai pusat sumber belajar masyarakat;

b. Menjamin ketersediaan layanan perpustakaan secara merata di tanah air

c. Menjamin ketersediaan keragaman koleksi perpustakaan melalui terjemahan (translasi), alih aksara (transliterasi), alih suara ke tulisan (transkripsi), dan alih media (transmedia)

d. Menggalakkan promosi gemar membaca dan memanfaatkan perpustakaan 
e. Meningkatan kualitas dan kuantitas koleksi perpustakaan

f. Membina dan mengembangkan kompetensi, profesionalitas pustakawan, dan tenaga teknis perpustakaan.

Dalam menangani permasalahan pengembangan perpustakaan sekolah/madrasah, tidak akan mungkin dibebankan tanggungjawabnya kepada pihak sekolah semata. Untuk itu dibutuhkan kekuatan sinergitas yang terdiri dari 3 komponen utama yaitu pemerintah, sekolah dan masyarakat dan hal ini sangatlah penting mengingat kompleksnya permasalahan dalam pengelolaan perpustakaan.

a. Komponen pemerintah

Pemerintah yang dilibatkan dalam pengembangan perpustakaan sekolah adalah Diknas, dan Badan Perpustakaan dan Badan Arsip Daerah (BAPERSADA). Ketiga lembaga ini turut memayungi an bertanggungjawab terhadap perpustakaan sekolah/ madrasah yang ada di daerah. Peran pemerintah daerah dalam pengembangan perpustakaan sekolah/madrasah memiliki dampak yang signifikan dan dapat diprediksi bahwa pengembangan perpustakaan akan mengalami masa depan suram (jalan ditempat) karena kurangnya perhatian pemerintah daerah. Upaya apapun yang dilakukan jika tidak dilandasi dengan suatu kebijakan, tidak akan dapat memenuhi harapan da tujuan. Sehubungan dengan itu maka strategi utama yang harus dilakukan oleh daerah adalah "goodwill" dari pemerintah dengan sungguh-sungguh mengandekan pembangunan perpustakaan sehingga menjadi prioritas melalui penyusunan kebijakan tentang pengembangan perpustakaan sekolah/madrasah. ${ }^{18}$

${ }^{18}$ Kahar, "Pola Strategi Sinergis Pengembangan Perpustakaan Sekolah," 131. 
Mengingat akan pentingnya peran pemerintah dalam pengembangan perpustakaan sekolah/madrasah, maka sejauh ini keterlibatan pemerintah daerah Kabupaten Gowa terhadap pengembangan perpustakaan nampak sangat besar khususnya bagi madrasah penerima pendidikan gratis. Kebijakan pemerintah daerah Kabupaten Gowa telah dirasakan oleh penyelenggara pendidikan madrasah melalui bantuan buku paket mata pelajaran umum dan mata pelajaran yang di ujian nasional serta buku bacaan lainnya yang berkaitan dengan pengembangan siswa, melalui bantuan Dinas Pendidikan dan Dinas Pemuda dan Olarhraga Kabupaten Gowa, walaupun jumlahnya belum maksimal dan belum sesuai dengan jumlah peserta didik yang ada.

Dalam kaitan ini, Kepala MAN Malakaji mengatakan bahwa untuk tahun 2014 pemerintah Kabupaten Gowa telah menyiapkan dana bantuan untuk pengadaan buku paket kurikulum 2013 yang diperuntukkan bagi madrasah penerima pendidikan gratis dengan jumlah yang berbeda pada tiap madrasah, untuk MAN Malakaji akan mendapatkan bantuan buku paket sebesar 20 juta rupiah. ${ }^{19}$

Sementara itu, peran lain yang dilakukan oleh pemerintah dalam hal ini Badan Perpustakaan dan Badan Arsip Nasional adalah 1) memberikan pelatihanpelatihan kepada tenaga perpustakaan yang ada di masing-masing sekolah/madrasah, walaupun sampai saat ini masih ada pengelola perpustakaan madrasah yang belum pernah mengikuti pelatihan perpustakaan 2) memberikan penilaian kepada perpustakaan sekolah/ madrasah dengan cara memberikan nomor pokok perpustakaan sehingga sebuah perpustakaan dapat dikategorikan sebagai perpustakaan madrasah yang baik

${ }^{19}$ Hanuwaruddin, interview. 
dan menjadi salah satu syarat untuk penilaian akreditasi sebuah madrasah.

Adapun peran Kementerian Agama baik pusat dan daerah walaupun dinilai masih belum maksimal terhadap pengembangan perpustakaan madrasah, khususnya dalam pengadaan gedung perpustakaan, sarana dan prasana lainnya, bahan koleksi pustaka terkait buku paket mata pelajaran PAI, pengembangan SDM bagi tenaga perpustakaan, kecuali pelatihan yang telah dilakukan oleh Badan Perpustakaan Nasioal dan UIN Alauddin Makassar yang melibatkan beberapa pengelola perpustakaan madrasah. ${ }^{20}$

b. Komponen sekolah

Pada tingkat madrasah, kepala madrasah merupakan figur kunci dalam mendorong perkembangan perpustakaan madrasah. Kepala madrasah dituntut berkomunikasi dengan baik dalam rangka menarik masyarakat, warga sekitar agar berpartisipasi dalam kegiatan pengembangan perpustakaan madrasah. Strategi yang dilakukan oleh kepala madrasah dalam pengembangan perpustakaan madrasah antara lain:

1) Menjembatani madrasah dengan masyarakat dalam hal pengumpulan dana dari orang tua siswa yang mampu, alumni untuk melengkapi sarana dan prasarana pengembangan perpustakaan madrasah

2) Melakukan mobilisasi untuk pengembangan perpustakaan sekolah melalui kerjasama dengan berbagai instansi baik swasta maupun pemerintah, baik dana maupun sarana dan prasarana.

c. Komponen masyarakat

Komponen masyarakat, juga memiliki peran penting dalam pengembangan perpustakaan madrasah dalam

${ }^{20}$ Hanuwaruddin. 
hal ini orang tua/wali siswa, tokoh pendidik, pelaku bisnis dan para alumni untuk senantiasa berperan aktif dalam pengembangan perpustakaan madrasah. ${ }^{21}$

Untuk menjamin eksistensi dari masyarakat, masyarakat harus tetap terlibat dalam setiap program-program pengembangan perpustakaan agar masyarakat tetap memiliki sence of belonging atau merasa handarbeni dengan keberadaan perpustakaan. Adanya suasana yang tidak membatasi ruang gerak masyarakat untuk membatasi tingkat partisipasi masyarakat mengakibatkan masyarakat dengan sepenuhnya akan peduli dengan perpustakaan. ${ }^{22}$

Mengingat akan kebijakan pemerintah daerah Kabupaten Gowa terhadap pendidikan gratis, maka komponen masyarakat tentunya dapat berperan aktif dalam pengembangan dan penyelenggaraan madrasah, khususnya bagi madrasah bagi penerima pendidikan gratis, sehingga kepala sekolah tidak dapat melibatkan masyarakat untuk memberikan bantuan terhadap penyelenggaraan perpustakaan.

\section{Simpulan}

MAN 1 Malakaji telah memiliki sarana dan prasarana perpustakaan namun perpustakaan tersebut belum dapat menjadi sumber belajar bagi siswa maupun bagi guru, sejauh ini perpustakaan hanya dijadikan sebagai salah satu pendukung dalam proses pembelajaran. Pengelolaan perpustakaan memiliki keterbatasan dengan konsep pengelolaan yang sangat sederhana dan jumlah koleksi yang terbatas serta sumber daya manusia 132-33.

${ }^{21}$ Kahar, "Pola Strategi Sinergis Pengembangan Perpustakaan Sekolah,"

22 Agung Nugrohoadhi, "Peran Serta Masyarakat Dalam Ikut Mengembangkan Perpustakaan - Agungnugrohoadhi," November 8, 2012, https://agungnugrohoadhi.wordpress.com/2012/11/08/peran-serta-masyarakatdalam-ikut-mengembangkan-perpustakaan/. 
belum sesuai dengan kualifikasi ilmu perpustakaan. Keberadaan perpustakaan dinilai masih jauh dari standarisasi pengelolaan perpustakaan berdasarkan Standar Nasional Perpustakaan baik dalam hal sarana dan prasarana, koleksi, tenaga perpustakaan, pengelolaan serta layanan.

Pengelolaan perpustakaan pada MAN 1 Malakaji telah melibatkan stakeholder baik pemerintah maupun masyarakat. Peran pemerintah dalam hal ini kementerian agama dan pemerintah daerah terkait pengadaan buku maupun sarana dan prasaran perpustakaan. Sedangkan komponen masyarakat melalui kerjasama yang kembangkan oleh pihak sekolah dengan harapan masyarakat memiliki kepekaan terhadap madrasah utamanya dalam pengembangan perpustakaan madrasah sebagai sumber belajar bagi siswa. 


\section{DAFTAR PUSTAKA}

Bafadal, Ibrahim. Pengelolaan Perpustakaan Sekolah. Jakarta: Bumi Aksara, 1996.

Cresswell, John. Research Design, Qualitative and Quantitative Approaches. California: Thousand Oaks, 1994.

Hanuwaruddin, March 3, 2014.

Indonesia. Undang-Undang Republik Indonesia nomor 43 tahun 2007 Tentang Perpustakaan. Perpustakaan Nasional, 2007.

Kahar, Irawaty. "Pola Strategi Sinergis Pengembangan Perpustakaan Sekolah.” Jurnal Tabularasa PPS UNIMED Vol. 6, No. 2 Desember (2009).

Masdiana, March 2, 2014.

Muslim, Abu. “Membaca Eksistensi 'Pusat Literasi'Dari Pelosok Negeri: Ironi Pengelolaan Perpustakaan Madrasah Aliyah Konawe Selatan." Penamas Vol. 28, No. 1, April-Juni, no. 1 (2015): 25-42.

- - - "Pengelolaan Perpustakaan Madrasah Aliyah Di KTI." In Desain Operasional Penelitian Balai Penelitian Dan Pengembangan Agama Makassar, 2014.

Nugrohoadhi, Agung. "Peran Serta Masyarakat Dalam Ikut Mengembangkan Perpustakaan - Agungnugrohoadhi," November 8, 2012. https://agungnugrohoadhi.wordpress. com/2012/11/08/peran-serta-masyarakat-dalam-ikutmengembangkan-perpustakaan/.

Perpustakaan Nasional, R. I. Standar Nasional Perpustakaan (SNP) Bidang Perpustakaan Sekolah Dan Perpustakaan Perguruan Tinggi. Jakarata: Perpusatakaan Nasional RI, 2011.

Perpustakaan Nasional RI. Daftar Tajuk Subjek Perpustakaan Nasional. Jakarta: Perpustakaan Nasional RI, 2010. 
- - - Standar Nasional Perpustakaan (Bidang Perpustakaan Sekolah Dan Perpustakaan Perguruan Tinggi). Jakarta: Perpustakaan Nasional RI, 2011.

Rahayuningsih, F. Pengelolaan Perpustakaan. Jogjakarta: Graha Ilmu, 2007.

Saputera, Agus. "Mengembalikan Peran Perpustakaan Sekolah/ Madrasah," March 3, 2010. https://riau2.kemenag.go.id/ artikel/10050/mengembalikan-peran-perpustakaansekolah-madrasah.

Sofyan, March 3, 2014.

Subair, Muh. "Standarisasi Pengelolaan Perpustakaan MA Di Kabupaten Gorontalo.” Jurnal Pusaka Vol. 2 No. 1 Mei (2014).

Yusuf, Pawit M., and Yaya Suhendar. Pedoman Penyelenggaraan Perpustakaan Sekolah. Jakarta: Prenada Media Group, 2007. 